\title{
A Comprehensive Study Plan for Identifying the Impact of Learning Styles, Teaching Strategies, Need for Cognition, and Meta-Cognition on Academic Achievement of Students in the Educational Centers
}

\author{
Mohsen Malekalketab Khiabani: International Business School, University Technology Malaysia, Postcode: \\ 54100, Kuala Lumpur, Malaysia.
}

\begin{abstract}
According to the extant literature, the positive roles of learning styles, teaching strategies, need for cognition, and meta-cognition on promotion and enhancing level of academic achievement is irrefutable. This study aims to plan for identifying the impact of mentioned variables on the academic achievement of students in the Educational Centers. The developed research model is based on a review in literature and is a comprehensive model which consists of four independent variables namely learning styles, teaching strategies, need for cognition, and meta-cognition. And one dependent variable that is academic achievement. In order to reach major and minor research objectives, the author develops a survey instrument with a proper standard and introduces a quantitative approach involving the distribution of questionnaires among students implementable in any educational centers. Total collected data can be analyzed through the Statistical Package for Social Science (SPSS) or Structural Equation Modeling via Analysis of Moment Structure (AMOS) program (SEM-AMOS). In order to answer research questions and testing developed hypotheses of this study, reliability test, descriptive statistics, factor analysis, correlation test, and multiple regression analyses can be run in SPSS and it can be run confirmatory factor analysis (CFA) in AMOS program with two-step strategy proposed by (Anderson and Gerbing 1988). The contribution of this scientific research will be pragmatic for academics in this research era because of the comprehensive research model. Also, this research has an outstanding role in bringing insight and realization for deputy deans, rectorates in the educational centers. Finally, the value of findings will be beneficial for promoting and increasing the level of academic achievement through learning styles, teaching strategies, need for cognition, and meta-cognition.
\end{abstract}

Keywords: Learning styles, Teaching strategies, Need for cognition, Meta-Cognition, Academic achievement, Educational centers.

\section{Introduction}

In a competitive era, all educators, universities counselors, and rectorates are looking for a way in order to gain a competitive advantage, especially sustainable competitive advantage. It is commendable to mention that many of them strive to survive in the tense competitive environment. One way to gain a sustainable competitive advantage is the possession of internal strength which can be obtained through the implementation of a basic strategy in order to promote the academic performance of students.

By reviewing in literature, it can be stated that scholars have pursued advanced studies for unearthing myriad instances in this research era and proposing models and introducing predictors which can play pivotal roles in increasing academic achievement of students. Based on studies by (Gupta ; Fayombo 2015; Akpur 2017) which will be reviewed in details in the literature review part of this study plan, literature review summarizes findings such as the significant impact of learning styles, teaching strategies, need for cognition, and meta-cognition on academic achievement. Therefore, this is an indication of researchers' attention and

Research in Social Sciences

2018

Email: mohse

Durding. This sketab@gmail.com

financial support.

Article History:

Received. 8 August 2018

Revised. 13 September 2018

Accepted: 15 October 2018

() 2018 by the authors; licensee Academic

Publishing Group 
managers who are implicated in this case. With these points in mind, the importance of academic achievement is undeniable, and it is worthwhile mentioning that no study to date has addressed a study with the purpose of planning to identify the impact of learning styles, teaching strategies, need for cognition, and meta-cognition in any educational centers till now in any countries within different scopes. By stating above notes and considering the significance of a study with mentioned objective, author of this research proposal has logical plan to develop a comprehensive research model. This study aims to plan to determine the impact of mentioned predictors on the academic achievement of students in the any educational centers and comprehensive model can be impolementable within any scopes regarding any educational centers in the world.

The remainder of this study plan is followed by an in-depth review of relevant previous studies, developing research model, stating major and minor research objectives, formulation of research questions and hypotheses based on existing literature. Thenceforth, research methodology including adapted quantitative method, target population or sample, and plan of data analysis for collected data will be explicated.

\section{Literature Review}

\subsection{Review of Relevant Previous Studies}

(Fayombo 2015) conducted a study in Barbados with the purpose of investigation of the effect of learning styles and teaching strategies on academic achievement. The scope within this scope was psychology students at the university of west indies. The author took a quantitative method involving the distribution of questionnaires among psychology students as stated earlier. A questionnaire with a proper standard of survey instrument based on measures introduced by previous scholars was developed. In this study, one hundred and seventy-one undergraduate psychology students were asked to complete the questionnaires. It is worthwhile mentioning that questionnaire design was based on independent and dependent variables. For the independent variables which are learning styles, author adapted VAK scale proposed by (Fardon 2013) for measuring learning style. Another independent variable in the study by (Fayombo 2015) is teaching strategies. And the dependent variable is academic achievement. That is why the author adapted acting learning strategies questionnaire introduced by (Felder and Brent 2005; Fayombo 2014) for measuring rest of variables. To data processing of collected data, SPSS was utilized by (Fayombo 2015). It is important to state that descriptive statistics and multiple regression analyses were run in SPSS in order to answer research questions, and testing developed hypotheses of the research. Findings supported the notion that learning styles and teaching strategies have a positive effect on the academic achievement of undergraduate psychology students in mentioned school with a beta coefficient of .226 and .369 respectively. This study brought insight and realization for academics in order to the promotion of academic achievement of psychology student through learning styles and teaching strategies. Therefore, according to the research by (Fayombo 2015), learning styles and teaching strategies are appropriate strategies for increasing level of academic achievement and implying important messages to managers at the university of west indies located in Barbados.

(Gupta) conducted a study in India in 2017 to find out the relationship of meta-cognitive skills, learning and teaching strategies on the academic achievement of secondary school students in the private school. The model of the study consisted of two independent variables which were meta-cognitive skills, learning, and teaching strategies. Also, academic achievement as a dependent variable. The author used the quantitative method and distributed 500 questionnaires among students. For the questionnaire design, the author cited the meta-cognitive skills scale proposed by (Gupta) and Suman in 2017. For measuring learning and thinking styles, the Indian version of style learning and thinking (SOLAT) tool introduced by (Venkataraman 2011). Collected data were processed using SPSS and running correlation, multiple regression analyses. Findings supported the positive effect of meta-cognitive skills, learning and teaching strategies on academic achievement with beta coefficients equal with .133 and .304 respectively. Based on obtained results, it is inferable that learning and thinking styles have more prediction in comparison with meta-cognitive skills among secondary school students in the private school. The contribution of the study has been valuable for educational thinkers, psychologists, teachers and others who are concerned with the sphere of education (Gupta).

(Akpur 2017) conducted a study in Turkey to identify prediction of metacognition and need for cognition on the academic achievement of students of a public university in Turkey. Therefore, research model of study by (Akpur 2017) consists of two independent variables which are meta-cognition and need for cognition and

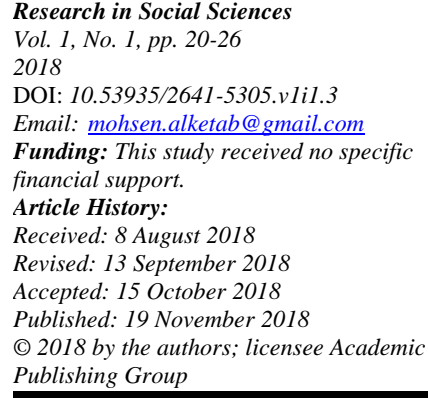


one dependent variable which is academic achievement. In order to achieve the objective of the research, (Akpur 2017) took a quantitative approach inclusive of distribution of 253 questionnaires among students who were participating in a public university in the academic year 2016-2017. Designing the questionnaire was based on scales introduced by previous scholars as stated by (Akpur 2017). For further explanation, (Akpur 2017) adapted the scale of Metacognitive Awareness Inventory (MAI) Scale proposed by (Schraw and Moshman 1995) for measuring meta-cognition. For measuring the need for cognition. (Akpur 2017) used originally developed scale introduced by (Cacioppo, Petty et al. 1984). For academic achievement, general points average (GPA) of students that they got during the term were taken into consideration. Total collected data was analyzed through SPPS and for determining the impact of meta-cognition and need for cognition, regression analyses were run. Findings of the study revealed that both independent variables have a positive prediction on academic performance. Meta-cognition had a result of equal with .28 beta coefficient and need for cognition had a result of .53 beta coefficient. It is worthy to highlight that research by (Akpur 2017) has been pragmatic for managers in public university and scholars who are concerned about predictors of academic performance (Akpur 2017).

Summarized information related to the review of previous studies is represented in table 1.

Table-1. Summary of Information Relevant to Reviewed Studies

\begin{tabular}{|c|c|c|c|c|c|}
\hline NO. & $\begin{array}{l}\text { Author/Year } \\
\text { /Country } \\
\end{array}$ & $\begin{array}{l}\text { Research Problem or } \\
\text { Dependent Variable }\end{array}$ & Research Model & $\begin{array}{l}\text { Research } \\
\text { Method } \\
\end{array}$ & Research Results \\
\hline 1 & $\begin{array}{l}\text { (Fayombo } \\
\text { 2015)/ } \\
\text { Barbados, } \\
\text { North } \\
\text { America }\end{array}$ & $\begin{array}{l}\text { Academic achievement } \\
\text { of psychology students } \\
\text { of at the university of } \\
\text { west indies }\end{array}$ & $\begin{array}{l}\text { Learning styles and } \\
\text { teaching strategies } \\
\text { as independent } \\
\text { variables, and } \\
\text { academic } \\
\text { achievement as a } \\
\text { dependent variable }\end{array}$ & $\begin{array}{l}\text { Quantitative } \\
\text { method/ } \\
\text { distribution of } \\
171 \\
\text { questionnaires }\end{array}$ & $\begin{array}{l}\text { Learning styles and } \\
\text { teaching strategies } \\
\text { have a positive } \\
\text { impact } \\
\text { academic } \\
\text { achievement with a } \\
\text { beta coefficient of } \\
.226 \text { and } .369 \\
\text { respectively }\end{array}$ \\
\hline 2 & $\begin{array}{l}\text { (Gupta)/2017 } \\
\text { / India }\end{array}$ & $\begin{array}{l}\text { Academic achievement } \\
\text { of secondary school } \\
\text { students in the private } \\
\text { school }\end{array}$ & $\begin{array}{l}\text { Two independent } \\
\text { variables which } \\
\text { were meta-cognitive } \\
\text { skills, learning, and } \\
\text { teaching strategies. } \\
\text { Also, academic } \\
\text { achievement as a } \\
\text { dependent variable. }\end{array}$ & $\begin{array}{l}\text { Quantitative } \\
\text { method/ } \\
\text { distribution of } \\
500 \\
\text { questionnaires }\end{array}$ & $\begin{array}{l}\text { A positive effect of } \\
\text { meta-cognitive } \\
\text { skills, learning and } \\
\text { teaching strategies } \\
\text { on academic } \\
\text { achievement with } \\
\text { beta coefficients } \\
\text { equal with } .133 \text { and } \\
.304 \text { respectively }\end{array}$ \\
\hline 3 & $\begin{array}{l}\text { (Akpur } \\
\text { 2017)/ } \\
\text { Turkey }\end{array}$ & $\begin{array}{l}\text { Academic achievement } \\
\text { of students of a public } \\
\text { university in Turkey }\end{array}$ & $\begin{array}{l}\text { Two independent } \\
\text { variables which are } \\
\text { metacognition and } \\
\text { need for cognition, } \\
\text { and one dependent } \\
\text { variable which is } \\
\text { academic } \\
\text { achievement. }\end{array}$ & $\begin{array}{l}\text { Quantitative } \\
\text { method/ } \\
\text { distribution of } \\
253 \\
\text { questionnaires }\end{array}$ & $\begin{array}{l}\text { Metacognition has } \\
\text { a result of equal } \\
\text { with .28 beta } \\
\text { coefficient and } \\
\text { need for cognition } \\
\text { had an effect of .53 } \\
\text { beta coefficient. }\end{array}$ \\
\hline
\end{tabular}

Research in Social Sciences Vol. 1, No. 1, pp. 20-26 2018 DOI: $10.53935 / 2641-5305 . v 1 i 1.3$ Email: mohsen.alketab@gmail.com Funding: This study received no specific financial support.

Article History:

Received: 8 August 2018

Revised: 13 September 2018

Accepted: 15 October 2018

Published: 19 November 2018

(C) 2018 by the authors; licensee Academic Publishing Group

\subsection{Developed Research Model}

Development of the research model of the present study is according to the in-depth review of literature of which was done earlier. For further explication, author of this study can deduce that there are several predictors which have attracted scholar's attention which are learning styles, teaching strategies, metacognition, and need for cognition. Thus, based on a review of related previous studies, the author can develop a comprehensive model which has not been addressed in the literature till now as illustrated in figure 1. 


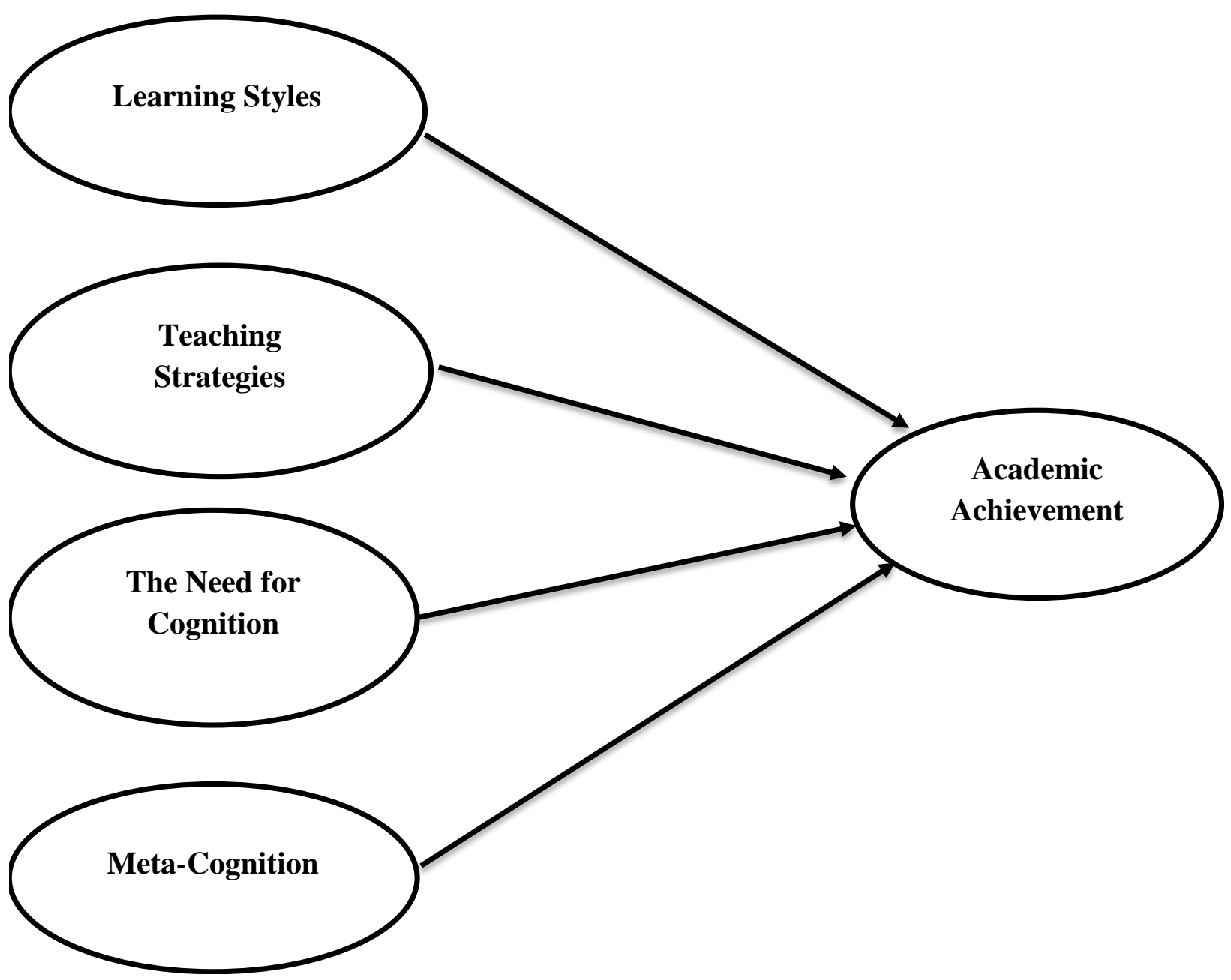

Figure-1. Comprehensive Research Model Based on Extant Literature

\subsection{Research Objectives}

The primary objective of this study is planning to determine the impact of learning styles, teaching strategies, need for cognition on the academic achievement of students in the education centers. To identify the overall relationship of mentioned independent variables on academic achievement (referring to figure 1), there are minor objectives which are delineated as indicated below:

- To identify the impact of learning style on the academic achievement of students in any selective educational centers.

- To identify the impact of teaching strategies on the academic achievement of students in any selective educational centers.

- To identify the impact of need for cognition on the academic achievement of students in any selective educational centers.

- To identify the impact of meta-cognition on the academic achievement of students in any selective educational centers.

Research in Social Sciences Vol. 1 , No. 1, pp. 20-26

DOI: $10.53935 / 2641-5305 . v 1 i 1.3$

Email: mohsen.alketab@gmail.com Funding: This study received no specific financial support. Article History:

Received: 8 August 2018

Revised: 13 September 2018

Accepted: 15 October 2018

Published: 19 November 2018

(C) 2018 by the authors; licensee Academic

Publishing Group

\subsection{Formulation of Research Questions (RQs)}

Referring to the research model in figure 1, "Academic Achievement"; to answer with this problem statement; the author needs to develop research questions based on research model that enables the author to find out specific required data. Therefore, based on the purpose of the present study, the author of the current research formulates following research questions for academic achievement.

RQ1: Does learning styles have positive impacts on the academic achievement of students in any selective educational centers? 
RQ2: Does teaching strategies have positive impacts on the academic achievement of students in any selective educational centers?

RQ3: Does need for cognition have a positive impact on the academic achievement of students in any selective educational centers?

RQ4: Does meta-cognition have positive impact on the academic achievement of students in any selective educational centers?

\subsection{Research Hypotheses}

According to the relationship between independent variables and academic achievement found in previous studies and the constructed model in this research based on literature, the author developed the main hypotheses of this study as follows:

H1: Learning styles have a poitive impact on academic achievement of students in any selective educational centers.

H2: Teaching strategies have a positive impact on academic achievement in any selective educational centers.

H3: Need for cognition has a positive impact on academic achievement of students in any selective educational centers.

H4: Meta-cognition has a positive impact on academic achievement of students in any selective educational centers.

\section{Recommended Research Methodology for Future Research Development \\ 3.1. Questionnaire Description}

Development of the questionnaire in this study is based on independent and dependent variables. At this stage, it is noticeable to explain designing the questionnaire is according to the scales introduced by previous scholars for each variable. The information related to the measurement of each variable are delineated as indicated below.

- For measuring learning styles, VAK test (Visual, Auditory, Kinesthetic) proposed by (Fardon 2013) can be utilized. The fundamental reasons that lie behind the selection of mentioned scale are that it has attracted researchers' attention and it is a highly cited and well-chosen scale based google scholar citations.

- For measuring teaching strategies, Active Learning Strategies Questionnaire proposed by (Felder and Brent 2005; Fayombo 2014) can be utilized. The fundamental reasons that lie behind the selection of mentioned scale are that it has attracted researchers' attention and it is a highly cited and well-chosen scale based google scholar citations.

- For measuring meta-cognition, the Metacognitive Awareness Inventory (MAI) proposed by (Schraw and Moshman 1995) can be utilized. The fundamental reasons that lie behind the selection of mentioned scale are that it has attracted researchers' attention and it is a highly cited and well-chosen scale based google scholar citations.

- For measuring the need for cognition (NFCS), scale proposed by (Cacioppo, Petty et al. 1984) can be utilized. The fundamental reasons that lie behind the selection of mentioned scale are that it has attracted researchers' attention and it is a highly cited and well-chosen scale based google scholar citations.

- For measuring academic achievement, scale proposed by (Fayombo 2015) which has three components: students' grades in coursework, students' grades in semester examination, and students' Learning Outcomes can be utilized. The fundamental reasons that lie behind the selection of mentioned scale are that it has attracted researchers' attention and it is a highly cited and well-chosen scale based google scholar citations.

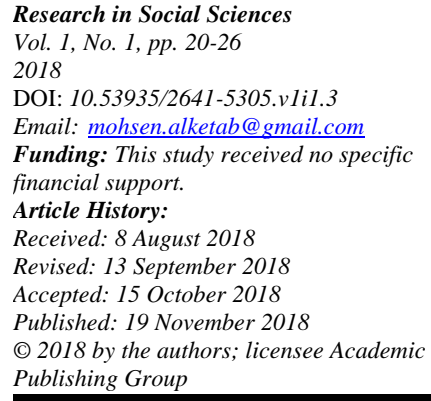

\subsection{Participants and Data Collection Procedure}

As stated in previous section (Section 3.1), the designed questionnaire can be distributed among students with the simple random technique or convenience technique in the any educational centers by scholars.

The simple random technique is a sampling procedure that assures each element in the population has an equal chance of being included in the sample, and no bias for selection of each participant is considered and 
convenience technique is a technique based on judgment of researchers for selection of each participant and also availability of each participant (Zikmund and Babin 2009).

\subsection{Plan of Data Analysis}

In the present study, total collected data from students in the any educational centers can be processed through SPSS software that is a sophisticated piece of software used by social scientists and related professionals for statistical analysis(Coakes, Steed et al. 2012) and collected data can be processed through SEM-AMOS. The following statistical tests explained in table 2 are recommended to be conducted in the SPSS or AMOS statistical programs to achieve required results.

\begin{tabular}{|c|c|c|}
\hline Item & Kind of Analysis & Description \\
\hline 1 & Reliability Test (SPSS) & $\begin{array}{l}\text { It is a test for measurement of internal consistency of items after finalizing } \\
\text { of data collection(Coakes, Steed et al. 2012). It ranges in value from } 0 \text { to } 1 \text {. } \\
\text { The value of . } 6 \text { is acceptable based on a note by (Cronbach 1951). }\end{array}$ \\
\hline 2 & Factor Analysis (SPSS) & $\begin{array}{l}\text { According to the (Coakes and Steed 2009), factor analysis is a data } \\
\text { reduction technique used to reduce a large number of variables to a smaller } \\
\text { set of underlying factors that summarize the essential information contained } \\
\text { in the variables. In this study to ensure the adequacy of sample size, the } \\
\text { normality of collected data, and calculation of factor loading for each item; } \\
\text { factor analysis will be performed in SPSS. }\end{array}$ \\
\hline 3 & $\begin{array}{l}\text { Descriptive } \\
\text { (SPSS) }\end{array}$ & $\begin{array}{l}\text { It is a practical analysis to explore the collected data and to summarize and } \\
\text { description of the data., calculation of mean, median, mode, and standard } \\
\text { deviation(Coakes, Steed et al. 2012) }\end{array}$ \\
\hline 3 & $\begin{array}{l}\text { Bivariate Correlation } \\
\text { Test (SPSS) }\end{array}$ & $\begin{array}{l}\text { This analysis refers to relationships between two variables which include } \\
\text { dependent and independent variables(Coakes, Steed et al. 2012). }\end{array}$ \\
\hline 4 & $\begin{array}{l}\text { Multiple Regression } \\
\text { Analyses (SPSS) }\end{array}$ & $\begin{array}{l}\text { Through conducting a regression analysis, researchers can predict the } \\
\text { correlation among independent variables with each other and with the } \\
\text { dependent variable. } \\
\text { Multiple regression analyses are an extension of the correlation test. The } \\
\text { result of the regression is an equation that represents the best prediction of a } \\
\text { dependent variable from several independent variables(Coakes, Steed et al. } \\
\text { 2012) }\end{array}$ \\
\hline 5 & $\begin{array}{l}\text { Running Confirmatory } \\
\text { Factor Analysis (CFA) } \\
\text { with Two-Step Strategy } \\
\text { proposed by (Anderson } \\
\text { and Gerbing 1988) }\end{array}$ & $\begin{array}{l}\text { Confirmatory Factor Analysis (CFA) in SEM technique is a sound method } \\
\text { for processing data and it is a covariance-based technique. SEM-AMOS is } \\
\text { based on sound methodological foundation and it has been highlighted and } \\
\text { attracted researcher's attention since one century ago(Blunch 2008; Blunch } \\
\text { 2012). }\end{array}$ \\
\hline
\end{tabular}

\section{References}

Akpur, U. (2017). The Predictive Degree of University Students'levels of Metacognition and Need For Cognition on Their Academic Achievement. European Journal of Foreign Language Teaching.

Anderson, J. C. \& D. W. Gerbing (1988). Structural equation modeling in practice: A review and recommended two-step approach. Psychological Bulletin, 103(3): 411.

Blunch, N. (2008). Introduction to structural equation modelling using SPSS and AMOS, Sage.

Blunch, N. (2012). Introduction to structural equation modeling using IBM SPSS statistics and AMOS, Sage.

Cacioppo, J. T., \& R. E. Petty, (1984). The efficient assessment of need for cognition. Journal of Personality Assessment, 48(3): 306-307.

Coakes, S., \& L. Steed, (2012). SPSS for Windows: Analysis without Anguish version 18.0. Australia: John Wiley \& Sons.

Coakes, S. J. \& L. Steed (2009). SPSS: Analysis without anguish using SPSS version 14.0 for Windows, John Wiley \& Sons, Inc.

Cronbach, L. J. (1951). Coefficient alpha and the internal structure of tests. Psychometrika, 16(3): 297-334.

Fardon, M. (2013). Relationships between students' learning style preference and exam achievement in differing forms of assessment during an advanced apprenticeship at a vocational Further Education College. Institute of Learning, Department of Education, University of Oxford. Retrieved from. 
Fayombo, G. (2015). Learning styles, teaching strategies and academic achievement among some psychology undergraduates in Barbados. Caribbean Educational Research Journal, 3(2): 46-61.

Fayombo, G. A. (2014). Enhancing learning outcomes in Psychology through active learning strategies in classroom and online learning environments. International Journal of Learning and Development, 4(4): 114-130.

Felder, R. M. \& R. Brent (2005). Understanding student differences. Journal of Engineering Education, 94(1): 57-72.

Gupta, M. Meta-Cognitive Skills and Learning \& Thinking Style: Predicting Academic Achievement among School Students.

Schraw, G. \& D. Moshman (1995). Metacognitive theories. Educational Psychology Review, 7(4): 351-371.

Venkataraman, D. (2011). Style of Learning and Thinking (SOLAT)." Psy-Com Services, New Delhi.

Zikmund, W. G. \& B. J. Babin (2009). Essentials of marketing research, South-Western Pub.

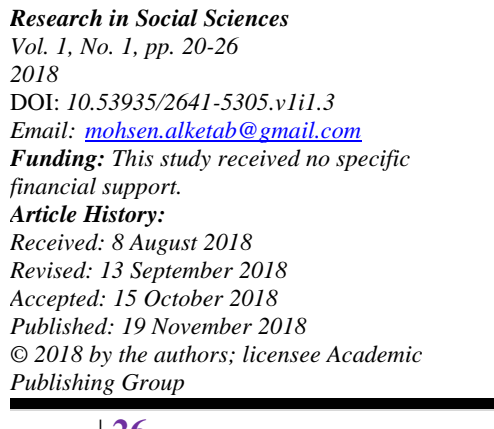

